\title{
From Comedy Targets to Comedy-Makers: Disability and Comedy in Live Performance
}

\begin{abstract}
The stand-up comedy landscape has been transformed in recent years with an increased number of disabled comedians performing. Via semi-structured interviews with disabled comedians, this article provides a thematic analysis of the material and ideological motives, intentions and lived experiences of disabled comedians. Two themes are discussed - comedy management and control; and affirming disability through comedy. These themes are characterised by complexity and contradictions. The article concludes that, although not a straightforward process, stand-up comedy enacted by disabled comedians is potentially a powerful tool through which hegemonic norms around disability can be challenged and renegotiated.
\end{abstract}

Keywords: Disabled comedians, stand-up comedy, management and control, affirming disability

\section{Introduction}

Over the last decade the stand-up comedy landscape has diversified with the steady increased presence and prominence of disabled comedians performing live comedy routines. As Shakespeare observes that 'stand-up comedy' is 'perhaps an unfortunate label in this context' (1999: 47), 'stand-up comedy' is used here to refer to a widely recognised specific style of comic expression in the Anglosphere. This diversification in stand-up comedy performers is evident in a number of countries including the United Kingdom (e.g. Abnormally Funny People, Matt Fraser, Francesca Martinez, Dan McKee and Liz Bentley), United States of America (e.g. Comedians with Disabilities Act, Josh Blue and Asperger's Are Us), Australia (e.g. Adam Hills, Steady Eddy, Imaan Hadchiti and the late Stella Young) and Canada (e.g. Tanyalee Davis). Francesca Martinez won the Daily Telegraph Open Mic Award at the Edinburgh Festival Fringe, in 2001 (the Edinburgh Festival Fringe is the world's largest art festival that has taken place every August since 1947 and showcases a range of performing arts including theatre, comedy, music and dance). Since 2003 Laurence Clark has had eight critically-acclaimed shows at the Edinburgh Festival Fringe and Abnormally Funny People took their first one-hour show to the Edinburgh Festival Fringe in 2005 (and their 10year anniversary show in 2015). A blogger on the BBC's Ouch! disability website noted that a 'plethora of disabled comedians' (Tracey 2012) participated in the Edinburgh Festival Fringe in 2012. Disabled comedian Tim Renkow won the Amused Moose Laugh Off at the Edinburgh Festival Fringe in 2014. Furthermore, a number of disabled comedians, such as Francesca Martinez, Adam Hills and Tanyalee Davis, have achieved international acclaim, regularly touring across the globe.

Although these interesting shifts in the live comedy-scape have received journalistic attention (Cockburn 2012; Tracey 2012; Simmons 2013; Verrent 2014), little academic research has focussed on disabled comedians, their intentions, motives and experiences. The two academic articles that have explored disabled comedians performing on the live comedy circuit make strikingly similar observations. Reid, Hammond Stoughton and Smith employed a textual analysis to examine comedy performances by disabled comedians in America and concluded that disability and comedy 'are interactive and constructive processes that are complex and 
multifaceted and warrant considerably more academic attention' $(2006,614)$. Furthermore in her analysis of disability-related themes evident in disabled and non-disabled comedians performances at the Edinburgh Festival Fringe in 2008 and 2009, Martin argues that her research provides a 'snapshot' of the topic and future research should 'involve asking comedians about their motivation around material' $(2010,545)$.

Inspired by the conclusions of Reid, Hammond Stoughton and Smith (2006) and Martin (2010), this paper redresses the imbalance identified by explicitly focussing on the experiences of disabled comedians. More specifically, through a series of in-depth one-toone semi-structured interviews with disabled comedians who have performed live comedy, the article provides a preliminary assessment of the material and ideological motives, intentions and lived experiences of disabled comedians performing live comedy in Britain. Thematic analysis is used to firstly examine the production and enactment of stand-up comedy performed by disabled comedians in terms of its enabling functions for disabled performers; and secondly to unpack to what extent disabled comedians use the comic mode as a vehicle to subvert, challenge, critique and move beyond dominant stereotypes and caricatures surrounding disability and to counteract disabling practices. By foregrounding the personal experiences of disabled comedians this article responds to the criticism that Disability Studies has largely focussed on physical and environmental barriers and public experiences to the detriment of examining everyday lived experiences (see Thomas 1999; Reeve 2004; Cameron 2009).

\section{Comedy and disability in context}

Comedy and disability have a complex and long relationship. On the one hand, cultural norms restrict members of society from laughing at people with disabilities and many nondisabled people fear disability and perceive 'having a disability as tragic, pitiable, or just plain sad' (Haller and Ralph 2003). Yet on the other hand, across history, disabled people have been the source of humour. A large proportion of this history consists of jokes, words, images, comic narratives and humour that denigrate disabled people (Shakespeare 1999). Reid, Hammond Stoughton and Smith $(2006,631)$ refer to this denigrating humour as 'disabling humour'. From Aristotle, Plato and Socrates, to the fool and jester of the Middle Ages, to Elizabethan joke books, and freak shows of the $18^{\text {th }}$ and $19^{\text {th }}$ centuries and the introduction of asylums, such as Bedlam, impairments have been a source of amusement for non-disabled people (see Garland 1995; Barnes 1992; Clark 2003; Cross 2012). Haller and Ralph (2003) refer to this as the first phase of disability humour which often involved constructing people with psychological impairments as 'representative fools'.

Ridiculing disabled people is a 'major feature' (Barnes 1992, 14) of contemporary film and television (Clark 2003; Haller and Ralph 2003; Reid-Hresko and Reid 2005; Mallet 2009, 2010; Montgomerie 2010). Moreover, from vaudeville, Broadway and music hall, through to contemporary established stand-up comedy circuits, jokes about disability made by nondisabled performers have repeatedly circulated on the live stage. For example, in the first half of the $20^{\text {th }}$ century, Harpo Marx, the second eldest of the American family comedy act, the Marx Brothers, derived comedy from pretending he was unable to speak (Barnes 1992) and jokes about famous deafblind author Helen Keller spawned the Helen Keller joke genre (Haller and Ralph 2003). The first British disabled stand-up comedian, Barbara Lisicki (stage name Wanda Barbara), argues that non-disabled peoples' fear of disabled people and/or 
the fear of becoming disabled manifests itself in 'thinly disguised hostility and hatred' (1992, 66) evident in jokes about disabled people. Haller and Ralph (2003) refer to this as the second phase of disability humour, which was largely characterised by non-disabled people making jokes about disabled people and emphasising their 'limitations'.

Martin (2010) observes how derogatory and 'othering' language that was used in the 1970s and 1980s was prevalent in some comedy performances at the Edinburgh Festival Fringe in 2008 and 2009. More recently, due to 'its proliferation on the comedy circuit', some comedians have requested that fellow comedians refrain from using derogatory and disabling terms, such as 'midget' in their performances (Berliner 2013). Clark argues that, repeated over time such disabling jokes and terms have a number of negative effects including: 'damage done to the general public's perceptions of disabled people, the contribution to the erosion of a disabled people's "identity" and how accepting disablist comedy as the "norm" has served to exclude disabled writers/comedians/performers from the [comedy] profession' (2003; see also Barnes 1992).

Following the laying of the foundations of the modern social movement of disabled people in the late 1960s and early 1970s, and the rapid increased growth of political activity by disabled people during the late 1970s and 1980s (Campbell and Oliver 1996), the Disability Arts Movement 'emerged from the mid-1980s onwards as disabled people began to develop their own voices and perspectives' (Cameron 2009, 383). Disabled comedians, such as Barbara Lisicki, were part of the Disability Arts Movement which was rooted in the social model of disability and provided 'social spaces in which disabled people could come together to share and explore with each other insights and perspectives that had previously only been experienced individually' (Cameron 2009, 384). Such spaces included disability arts cabarets, workshops and festivals. Over the last decade there has been a continual increase in the number of disabled comedians performing live comedy in a number of countries, including the United Kingdom, America, Australia and Canada. Performers such as Laurence Clark, Liz Carr, Josh Blue, Imaan Hadchiti and Tanyalee Davis are making jokes about impairment and their experiences of disability. Reid, Hammond Stoughton and Smith $(2006,631)$ refer to this type of humour as 'disability humour'. Whilst disabled comedians, such as Barbara Lisicki, were performing comedy when the Disability Arts Movement began, they were fewer in number and less customary to mainstream audiences than disabled comedians currently performing. Although when compared to the number non-disabled comedians, disabled comedians 'remain rare' (O'Hara 2006), currently, disabled comedians are creatively shifting the comedy spotlight from disabled people as the targets of comedy to disabled people as comedy-makers and are performing to disabled and non-disabled audiences in recognised comedy venues, unlike their earlier counterparts. Liz Carr argues ' ... people need to see that disabled people are funny ... You know, our lives are quite fascinating and there's a lot that people can learn from that' (quoted in O'Hara 2006). Reid, Hammond Stoughton and Smith refer to comedy performed by disabled comedians as an 'emerging, liberatory art form' $(2006,640)$ and Haller and Ralph (2003) refer to this shift as the third and fourth phases of disability humour. The third phase is 'characterized by people with disabilities taking control of the humour message', where humour 'doesn't just go for the laugh; it allows non-disabled people to see issues related to disability in a different light'. The fourth phase focuses on comedy about disability that focuses on "normalcy, equality, and "bold honesty". Building on these shifts and changes within the comedy industry, this empirical article aims to specifically examine the material and ideological motives, intentions and lived experiences of disabled comedians who have performed live stand-up comedy in Britain. 


\section{Methodology}

In order to address these research aims, a series of one-to-one semi-structured interviews with disabled comedians was conducted. 'Snowball sampling' (Sturgis 2008) was implemented in order to recruit comedians to the research. This involved asking those comedians who had participated in the semi-structured interview if they knew other comedians who may be willing to be interviewed and following-up any suggestions made. Fifteen comedians, each self-identifying as a disabled comedian, were interviewed. All interviewees permitted the use of their names in the write-up of the research. Interviewees were: Liz Bentley, Gareth Berliner, Paul Betney, Liz Carr, Laurence Clark, Carl Cullinane, Tanyalee Davis, Imaan Hadchiti, Dan McKee, Simon Minty, Liam O’Carroll, Lost Voice Guy (Lee Ridley), Caro Sparks, Kiruna Stamell and Shaun Turner. Steve Best, a non-disabled comedian was also interviewed due to his comedy production experience. Steve Best is co-founder and coproducer of a group of stand-up comedians called Abnormally Funny People and describes himself as the group's 'token non-disabled comedian'. The comedians interviewed differed in terms of the length of time they have been performing stand-up comedy (e.g. Tanyalee Davis had been performing stand-up full-time for fourteen consecutive years at the time of interview and Lost Voice Guy had been performing nine months), the nature of their impairment (physical, sensory and/or mental illness) and the length of time impairment(s) had been present (ranging from birth to onset during early childhood or early adulthood). Such heterogeneity strengthens the research as it facilitates understanding of the livedexperiences of disabled comedians from a range of perspectives. Interviews took place between July 2012 and June 2014 and sought to examine in detail the experiences, perceptions, motives and value of performing stand-up comedy for disabled comedians. The transcribed interview data were analysed using qualitative thematic analysis (Aronson 1994; Braun and Clarke 2006). Thematic analysis is a 'method for identifying, analysing and reporting patterns (themes) within data' (Braun and Clarke 2006, 79) and focuses on 'patterns of living and/or behaviour' (Aronson 1994).

\section{Findings and analysis}

The thematic analysis identified two main interconnected themes in the comedian interviews: 1) Comedy Management and Control; and 2) Affirming Disability through Comedy. These two themes were characterised by complexity and contradictions. It is to these two themes that we now turn.

\section{- Comedy management and control}

A key theme identified in the data specifically related to the appeal of stand-up comedy in terms of the management and control facilitated by this particular mode of comic expression. Comedy management and control is manifest at two different and distinct levels: management and control of comic material; and management and control of stand-up comedy audiences.

\section{- Comic Material}

When describing the appeal of stand-up comedy, Liam O'Carroll argued 'you're in control of 
it, and your material and it's just the simplicity of it, it's just you going up there and doing it'. Further Imaan Hadchiti explained 'you can be your own boss. You make your own work'. Similarly, Gareth Berliner maintained 'I like the fact that you're in complete control, so you're the director, the authorship, you're the author completely'. Kiruna Stamell, who is a stand-up comedian, actress and dancer, explained the appeal of stand-up by comparing her stand-up comedy experiences with her acting experiences and making clear distinctions between these two types of performance in terms of the different opportunities for personal expression:

Stand-up gave me an avenue to explore the tangent ideas around myself, life and world, as a real life human versus the pretend characters that were being created for me, so there was a bit of a split there. It was an opportunity for me to have a bit more control, to take the reins, and to express myself in a different way.

Similarly Liz Bentley explained that comedy:

Is the only thing that seems to work for me. I have to write my own stuff. I did do drama, I did adult education and did a 2 year drama course, but I never really enjoyed it because I wanted to write myself. Comedy just seemed to be a way of getting things out and being listened to in a particular way.

Stand-up comedy thus offers a socially accessible space for disabled comedians who can control their participation in this particular social environment. Such responses are united in the way in which they recognise the positive benefits of self-definition and self-authorship in comic performance. These responses resonate with Francesca Martinez' reflections on her early experiences of performing stand-up comedy: 'when I performed, it was my take on life that mattered. I choose what were used and what perspective was shared with the audience. It was an empowering feeling to turn parts of my life into comedy' $(2014,248)$. Such responses also reaffirm Hughes and Románs' (1998) findings in their exploration of the reasons that queer artists are attracted to solo performances. They found that, in addition to the relatively low costs and limited time involved with this type of performance, queer artists are attracted to solo performance due to the opportunities provided to define their own identities and to critique their communities, and the flexibility provided as casting directors and their prejudices do not come into play.

\section{- $\quad$ Comedy audiences}

In addition to the management and control of comic material, stand-up comedy appealed to some interviewees due to the immediacy of creating a response in the audience. Liz Carr described how she 'loves the immediacy of response' and 'loves that power' of generating an immediate response in the stand-up comedy audience. Some comedians discussed the ways in which their impairment could be incorporated into the comic performance in order to manage the audience and to create an immediate reaction, particularly a noisy, late-night and drunken audience. Gareth Berliner, who has Crohn's disease, recounted a particular performance when he foreground the medical/physical signifier of disability into his comedy performance as he used the nutritional feed tube in his chest to control the audience:

It was two in the morning, they [the audience] were just shouting and drunk, I was 
told before I went on, 'just try and get through it, don't worry' I went on and I normally get to the health stuff after doing several bits, I literally went on stage, lifted my shirt and go, 'do you guys want to hear something you've never heard about, check this out' [lifts shirt to show the nutritional feed tube in his chest]. The whole room shut up, just absolutely quiet and I was able to do my stuff. On that level, getting an audience's attention, shutting them up for a minute, it's brilliant.

These comments suggest that stand-up comedy provides disabled comedians with the opportunity to fully participate in public communication and elicit a sense of control over the audience in terms of when, and, to a certain extent, how it responds in relation to the comic material and how disabled comedians may incorporate their impairments and related 'stigma symbols' (Goffman 1963, 59) into their performance via 'purposeful slips' (Goffman 1963, 124) to occasion audience control. Stand-up comedy offers some disabled comedians the opportunity to redistribute 'interactional power' (Fairclough 1989; Tannen 1987).

Interactional power is 'created when a participant is perceived by others to be more dominant, hold higher status, or be an expert or an authority' (Simmons-Mackie and Damico 2011, 87). Gaining interactional power is significant as it demonstrates how disabled comedians 'refuse to occupy the bottom rung of the social hierarchy' (Reid, Hammond Stoughton and Smith 2006, 638). This 'interactional power' is additionally important as it facilitates self-definition, which is central to counteracting objectification and dehumanization of the 'other' and shifting specific identities from the object to the subject of comedy. In her analysis of women and comedy, Merrill argues that 'seizing and redefining the apparatus of comic perspective so that it is inclusive of women's experiences is a necessary and powerful gesture of self-definition (1988, 279-280). The above responses suggest that that same applies to disabled peoples' experiences - by controlling the comic performance disabled comedians can claim, or reclaim, subjectivity.

\section{- $\quad$ Limits to comedy management and control}

The positive experiences gained through the feelings of control and management generated by writing and performing stand-up comedy can, however, be negated by various types of barriers that were referred to by a number of comedians during the interviews. A specific barrier related to ways in which fellow comedians attempt to define impairments and disability. For example, Liam O'Carroll recounted various instances where compères had made jokes about his blindness:

There were a couple of times where compères tried to make jokes about me being blind and I didn't really like it. It wasn't to my taste and it's not how I wanted to be introduced to the audience. I wanted to control how my blindness was made funny. I wanted to have a say in that and that kind of got on my nerves a bit.

Compères play a significant role in framing stand-up comedy performances. In his analysis of stand-up comedy compère introduction sequences, Rutter observes that compères provide 'a foundation onto which the comedy that follows is built' $(2000,463)$. Through standard introductory techniques, such as contextualisation, appraisal and evaluation, compères help to frame audiences' attitudes towards, and expectations of, comedians before they enter the 
stage. Such introductory techniques are usually positive and favourable towards the comedian and provide the audience with an 'opportunity to begin to see the oncoming comedian not only as a generic performer, but as an individual comedian' (Rutter 2000, 481). However, as Liam O'Carroll's experiences highlight, occasions where compères attempt to describe, and fix, a comedian's identity by focussing on aspects of his/her identity that are perceived by compères to individualise the comedian, can have a negative and detrimental effect when compères specifically focus on a feature of the comedian's identity that the comedian is deliberately attempting to challenge and critique in his/her performance.

Furthermore, physical barriers created by the performance space in stand-up comedy venues were repeatedly highlighted as limiting the comedian's ability to control the performance. Liz Carr, a wheelchair user, explained the negative impact that an inaccessible stage had on her ability to relax into her comedy set:

I'd be lifted on to a stage in front of the audience, that already sets you in a position of great inequality, and sets up a great fear with the audience, and then I'd be on the stage and couldn't get off. On the stages I was on, I'd had to have gone, 'I need to get off now', and that set up a whole dynamic in me, that I was doing comedy and nobody would ever know that inside I was going, oh my god I can't get off the stage, what am I going to do, so I was having this dialogue internally whilst at the same time delivering gags. On the whole I was getting away with it, but of course you're not totally present in the gig then, and the best gigs are when you're relaxed.

Similarly Lost Voice Guy reported that 'it doesn't help that most clubs are down a million stairs. Getting up on stage can be hard too. Sometimes I get helped onto stage'. In addition to the performance space limiting or negating the control that disabled comedians experience, the opportunities for networking and being involved in discussions about future performances were limited for some disabled comedians due to the physical space that such informal discussions occur. Carl Cullinane explained how this had a negative impact on his comedy career progression:

In the venue, the biggest problem I have is socialising. The comedians are often hanging around round the back of the gig or they're hanging round in a staircase and that's how you meet people and get to know people and get offered gigs, and I think I miss out a lot of that because I don't feel comfortable standing around because if I'm standing for a while, I start to feel pain in my knees and I can't converse normally if I'm stressed and have to sit down. So that holds me back and that's frustrating.

These shared experiences illustrate the ways in which the social and physical features of the

institution of stand-up comedy create specific barriers for some disabled comedians, which have the potential to counteract the positive management and control aspects of standup

comedy performances for disabled comedians.

\section{- Affirming disability through comedy}

The majority of interviewees identified that being entertaining was the primary goal of their 
stand-up comedy performances. Dan McKee explained that 'the reason I'm there is to make people laugh and to do my job as a comedian, that's it' and Simon Minty argued that his purpose as a comedian is to 'make people laugh'. However, most interviewees recognised secondary functions or 'by-products' (Simon Minty; Laurence Clark) of their comedy. The secondary functions related to the different ways in which disability can be affirmed through comedy via increasing understanding and educating audiences about disability. Lost Voice Guy argued that 'I just like making people laugh. If it helps give people a better understanding of disability though, that's a good thing'. Similarly Laurence Clark explained that his main job 'is to make people laugh, not to educate people; if they go away with that as a by-product then great, but my main job is to make them laugh.' Liz Carr observed 'whatever we do [disabled comedians] is often being viewed, and people will make decisions on that. I think, to a degree, whatever you do on stage, people are going to take something away from it about disability'. Kiruna Stamell explained how that although she is not consciously trying to educate audiences about disability she does aim to 'tickle their brains a bit and get them to think. If they go away having learnt something, I think that is a bonus.'

A number of interviewees explained how live stand-up comedy enabled them to 'connect with people' (Liz Carr), to 'build a bridge' (Liam O'Carroll) between disabled and nondisabled people, to 'bring an audience into my world' (Gareth Berliner), to 'bring the audience on board' with their perspective (Shaun Turner) and 'breaking down barriers' (Tanyalee Davis) between those who have an impairment and those who do not, or those who have an impairment but do not identify as disabled or subscribe to a different political stance about impairment and disability than that shared by the disabled comedian. Three specific inter-connected performative features of stand-up comedy were identified as facilitating connection making or bridge building. These were authenticity, reversed discourse and shared laughter.

\section{- $\quad$ Authenticity}

A number of comedians interviewed described their comedy performances as being underpinned by a sense of reality and authenticity. Liz Bentley described her performance as 'very personal, very authentic' and Gareth Berliner described his comedy material as 'very open. Very real, there's not a lot of my stuff that's made up. Partially observational, mainly autobiographical', Liz Carr explained how her performance is 'very much' her 'take on the world'. Furthermore, Tanyalee Davis argued 'by talking about all my life experiences I think it opens people's eyes. I'm not making fun of myself; I'm making fun of situations I get into because of my height, or lack thereof'. Shaun Turner explained that by saying 'look this has happened, it's a bit crap but in a way it's kind of funny and it's okay. It's getting people on your side and accepting that cerebral palsy is just a part of life'. In these instances the comic gaze is directed towards impairment and the experiences of disability, thus making disability visible. For these performers stand-up comedy is a useful form of communication as it enables 'the audience to see and hear about the disability experience first-hand' (Reid-Hresko and Reid 2005) and enabled disabled comedians to 'reveal that their lives are full, rich and well worth living' (Reid, Hammond Stoughton and Smith 2006, 633). Furthermore, these honest and personal stories and experiences shared through the medium of stand-up comedy provide interesting and welcome relief from figuring disability within the 'dual tropes of disease and dependency' and the 'sanitizing of disability' which includes 'rendering it entirely unproblematic (because invisible) for non-disabled society' (Ross 2001, 425-426; emphasis in original). These examples suggest that performances by some disabled 
comedians are representative of the affirmation model of disability (Swain and French 2000; Cameron 2015), which builds on the social model of disability and critiques the medical model of disability. The affirmation model, which has origins in the Disability Arts Movement, and is based on the experiences and perspectives of disabled people, is a 'nontragic view of disability and impairment which encompasses positive social identities' which has 'arisen in direct opposition to the dominant personal tragedy model of disability and impairment' (Swain and French 2000, 569). It asserts that living with impairment and disability can be 'valuable, interesting and intrinsically satisfying' (Cameron 2015, 110) and foregrounds impairment as an ordinary part of human existence. By collectively embracing positive individual and collective identities through their comedy on their own terms, disabled comedians can begin to confront negative stereotypes surrounding impairment and disability, which is a central feature of the affirmation model (see Swain and French 2000).

\section{- $\quad$ Reversed disability discourse}

An alternative way in which some disabled comedians affirm disability is to turn to the comic gaze away from their impairment to the disabling stereotypes held by non-disabled people or disabled people who do not self-identify as disabled or have a different political view of impairment and disability, and the problematic encounters that they experience with such individuals. Although the comedy still communicates experiences of being disabled in contemporary society, crucially it switches the comic gaze outwards towards disabling social norms and critiques disabling stereotypes. Simon Minty observed how his best comedy was that which critiqued disabling encounters and behaviour:

My best comedy was where the audience get slightly uncomfortable and then start laughing, because they're recognising something about their behaviour. So disability comedy really works well when the audience is not laughing about impairment, it's laughing about how society's set up and doesn't work and that includes them.

Liam O'Carroll also recounted a particular joke in which he deliberately inverts, or reverses, the authentic experiences of disabled people and the behaviour of non-disabled people or disabled people who have different political views surrounding impairment and disability. This comic rhetorical strategy is utilised to illustrate the absurdity that underpins nondisabled expectations about disabled people and the offensive comments that non-disabled people sometimes make when interacting with disabled people:

I did a one man sketch in which I was inverting a situation where the whole world was blind and there was a sighted person at the meeting. It was a committee meeting and it inverted an experience I'd had. Everyone was blind and there was one sighted person who hadn't been catered for in this meeting. It was a line like, 'I'm sorry you've had this. It's just you wouldn't think you could see to look at you.' When normally that line is, 'sorry, you wouldn't think you were blind to look at you,' which is a line I often get.

These types of jokes may be interpreted as a source of reverse disability discourse in comedy performed by disabled comedians. Reverse humour is a discourse: 'whose etymology can be traced, often in quite evident manner, to an earlier discourse that uses identical signs but which employs these signs for a reverse semantic effect' (Weaver 2010, 32). The semantic 
reversal can be created by the changing social dynamics of the joke teller. Although, to date, reverse discourse has been identified as being primarily used by comedians such as Richard Pryor and Lenny Henry (Weaver 2010) for the purpose of articulating anti-racist comedy, here we see the application of a reverse disability discourse which employs disabling language and stereotypes in order to produce a reverse semantic effect or anti-disablist resistance. Although Liam O'Carroll's joke uses some of the tropes comparable to disablist humour, it differs significantly "because it is the "other" of the earlier discourse who articulates it' (Weaver 2010, 32), which in this case a disabled person. Stand-up comedy is utilised by some disabled comedians as vehicle to draw attention to the ways in which stereotypes about disability demeans and belittles disabled people and to call cultural values into question by ridiculing and challenging them. Thus comedy performed by some disabled comedians brings discrimination and oppression centre stage, but it goes beyond simply reflecting it to audiences by opening-up alternative ways of thinking about disability. Here we see similarities with the use of comedy in songs. As observed by Cameron in his analysis of comedy used in song lyrics performed by disabled singers and bands, 'they take delight in holding it up to the light and laughing at it. This involves not a denial of the reality of oppression, or a failure to take oppression seriously, but a way of thinking about it differently' (2009, 392-393; emphasis added). The laughter created by the comedy performances is an essential component of making connections and building bridges between disabled and non-disabled people, and/or non-identifying disabled people and/or disabled people with different political perspectives.

\section{- $\quad$ Shared laughter}

A number of disabled comedians discussed the importance of sharing laughter with their audiences. As Double argues, 'much of what stand-up comedians do is about sharing: shared feelings, shared experiences, creating a sense of community with the audience' $(2014,206)$. Creating a sense of cultural community between the comedian and audience is a key component of successful stand-up comedy (Mintz 1985). Creating and sharing laughter is central to creating and sustaining this sense of cultural community. In her discussion of how she 'reunites the [disabled and non-disabled] worlds', Caro Sparks explained that:

The best way to open people up is to make them laugh and if you can tell stories that inform them about your experience and your perspective through humour, then people are more open to understanding who you are and where you're coming from. And if we can laugh together, we can live together. If I can introduce sign language in a way that's creative, that's funny, that's safe, then people will be more open to it.

Similarly, Imaan Hadchiti highlighted the important role fulfilled by shared laughter during stand-up comedy performances in helping to normalise disability and difference:

Stand-up is the best way to get your point of view across and champion whatever and normalise it, to show an audience, I'm different but we're sharing laughter. If you share a laugh with someone, you're friends with them instantly.

In his analysis of the meaning of laughter, Bergson (1911/1999) highlights the social aspect of laughter and the importance of feeling connected to others that are involved in the creation and experience of laughter. Bergson argues that 'you would hardly appreciate the comic if 
you felt yourself isolated from others ... Our laughter is always the laughter of a group (1911/1999, 11). Laughter can reduce social distance between people with/without impairments and increase understanding of disability as relationships are built and sustained through shared appreciation of comedy and laughter (Provine 2000). In her analysis of humour used in hospital settings, Coser $(1959,172)$ observes that 'to laugh, or to occasion laughter through humor and wit, is to invite those present to come close. Laughter and humor are indeed like an invitation, be it an invitation for dinner, or an invitation to start a conversation: it aims at decreasing social distance'. As Reid, Hammond Stoughton and Smith argue, comedy performed by disabled people 'elicit[s] thought-provoking laughter' and it is through comedy that disability is presented 'as an interesting way to live' $(2006,629)$. Given that our behaviours, beliefs and expectations about ourselves and others are socially constructed through face-to-face interactions (Blumer 1969; Garfinkel 1967; Goffman 1974), and coupled with the social benefits of shared laughter, stand-up comedy is a useful vehicle through which beliefs and expectations surrounding impairments and disability can be negotiated and re-negotiated and co-constructed by disabled comedians and audiences.

\section{- $\quad$ Limits to affirming disability through comedy}

Telling jokes and comic narratives about impairment and disability does not 'result in an unproblematic promotion of disability rights and interest' (Montgomerie 2010, 98) or a straightforward increase in understanding of disability and reduction in social distance. As discussed above, the positive experience of disabled comedians performing stand-up comedy in terms of the management and control can be hindered by physical and social institutional features of stand-up comedy. Limits to affirming disability through comedy are primarily experienced as a result of audience perceptions of, and responses to, someone with an impairment performing comedy. As Double (2014) argues, the audience plays a central role in the stand-up comedy process and the impact of stand-up comedy performances is partly contingent upon audience interpretation. Some comedians with visible impairments referred to the necessity of addressing the tension that their impairments cause for some stand-up comedy audience members from the outset of their comedy performances. This often involves immediate and direct references to their impairment and sharing feelings of difference. For example, Carl Cullinane explained that when he first appears on stage he asks if anyone is from ATOS (the company that assesses whether benefit claimants in Britain are fit to work), then drops his crutch and then says, 'you can never be too careful', which 'pretty much always gets a big laugh' because:

It releases tension in the audience because they're not used to seeing someone get on stage with a crutch and I kind of hold myself in an awkward way initially and then I let go of it and then I relax, and I think that helps people relax as well, and also they feel like they can laugh at it also, the fact that I've mentioned it.

Furthermore, Liz Carr explained that rather than introducing herself as a wheelchair user, she asks the audience:

If there are any social workers in the audience, and then I'm relieved if there aren't, or if there are I can make a joke about that, because otherwise I say, 'I'm going to have sit here...', I look like I'm dribbling and everything, my head's down and I struggle to hold the mike. What that's doing at least is a) it's making a political point but b) it is also saying, 'I know I'm disabled, it's okay, and we're safe here. 
As Shakespeare argues, when in the 'presence of disabled people, most non-disabled people feel a certain tension ... and may be both ignorant of what is expected, and anxious about saying the right thing' $(1999,49)$, which can hinder communication flow and can prevent rapport-building. The comic devices described, and used, by some of the disabled comedians serve a dual social purpose. They acknowledge impairment whilst simultaneously highlighting that the comedian is comfortable with his/her impairment and that it is unimportant, which serves as a signal that the interaction can advance (Shakespeare 1999). Different comic strategies tend to be employed by different disabled comedians depending on whether or not their impairment is visible or unseen. As Goffman argues, when impairments are visible and known to members involved in the social interaction, tension management and control is significant (as with Carl Cullinane and Liz Carr above). Whereas, when impairment is invisible or unknown, as we saw above with Gareth Berliner when discussing the reveal of his nutritional feed, the 'issue is not that of managing tension generated during social contact, but rather that of managing information ... to display or not to display; to tell or not to tell; to let on or not to let on ... to whom, how, when, and where' (Goffman 1963, 57). Thus, visible and invisible impairments proffer different performance opportunities and facilitate different performative techniques. However, the effectiveness of these rhetorical strategies is not a straightforward process. For example, some disabled comedians reported that despite their visible impairment, some audience members perceived that they were pretending to be disabled or is 'faking it'. Shaun Turner recounted how he 'had a conversation with someone, post-gig, who thought that I made having cerebral palsy up, thought that I faked it'. Similarly, Paul Betney described a particular performance where 'two guys threatened me because their brother had some neurological disorder and they thought I was pretending for laughs'.

\section{Discussion}

This article has contextualised the experiences of disabled performers within the institution of stand-up comedy. It has provided thematic analysis of the material and ideological motives, intentions and lived experiences of disabled comedians who have performed live stand-up comedy in Britain. The two main themes identified - comedy management and control; and affirming disability through comedy - demonstrate that stand-up comedy offers disabled comedians a vehicle of social critique through which to express aspects of their identity and their experiences that mainstream society ignores or actively silences (Sandhal 2003), to challenge and renegotiate hegemonic norms around disability and to humanise disability in the public sphere. As Haller (2003) argues such comic performances 'appear to be a way in which the disabled community is gradually sliding its issues into the mainstream culture'. However, shifting the comic focus from impairments and disabled people as the targets of comedy, to disabled comedians owning and making comedy, is not a simple and straightforward process. There are specific physical, social and relational features of standup comedy venues and the comedy process that limit and counter the positive experiences and outcomes reported by disabled comedians. It is also important to acknowledge whist some of the material and ideological motives, intentions and experiences are specific to disabled comedians - such as using disability to control comedy audiences, providing disabled authenticity and utilizing reversed disability discourse - others are applicable to any comedian, disabled or non-disabled - such as stand-up comic performance providing a sense of control over material and shared laughter reducing social distance between the comedian and audience. 
Article 8 of the United Nations (UN) Convention on Disability Rights specifically aims to promote good relations between disabled and non-disabled people by combating 'stereotypes, prejudices and harmful practices relating to persons with disabilities' and promoting 'awareness of the capabilities and contributions of persons with disabilities' (2006). The experiences shared in the comedian interviews and the points raised above suggest that comic performances by disabled comedians should be perceived as valuable vehicles through which such Convention aspirations may be fulfilled. Furthermore, the experiences shared during the interviews lend empirical and theoretical support to Thomas' suggestion that 'putting disability comedy into the control of disabled people who ridicule disablism would go a long way towards culture change' $(2011,111)$ that she argues is necessary to challenge and counter the dominant culture which allows 'mate crimes' - 'considered actions against disabled people at the hands of someone, or several people that the disabled person considers to be their friends, or they may be relatives' $(2011,107)$ - to occur.

However, any potential benefits that disabled comedians may have for wider societal relations could be undermined given the reductions in the financial support available to disabled people in the United Kingdom. Jess Thorn, who performs as Touretteshero, combines storytelling, stand-up comedy and puppetry with her tics has argued that the Independent Living Fund (ILF) and Access to Work have made performing possible (see Verrent 2014). With the impending closure the ILF and the repeated reports that it is becoming increasingly difficult for performers to maintain their Access to Work support (Dawson 2014; Gardner 2014; Verrent 2014) the positive social and cultural impact that the increasing number of disabled comedians may have on society is being tempered by political and economic decisions. Without the right support we could return to a comedy landscape where comedy-making is largely the preserve of non-disabled people laughing at disability.

\section{References}

Aronson, J. 1994. “A Pragmatic View of Thematic Analysis." The Qualitative Report 2 (1). http://www.nova.edu/ssss/QR/BackIssues/QR2-1/aronson.html

Barnes, C. 1992. Disabling Imagery and the Media: An Exploration of the Principles for Media Representations of Disabled People. Derby: BCODP.

Bergson, H. 1911/1999. Laughter: An Essay on the Meaning of the Comic. Los Angeles:

Green Integer Books.

Berliner, G. 2013. "Midget' is a Dirty Word." Chortle: The UK Comedy Guide, March 19. http://www.chortle.co.uk/correspondents/2013/03/19/17458/midget_is_a_dirty_word

Blumer, H. 1969. Symbolic Interaction. Englewood Cliffs, NJ: Prentice-Hall.

Braun, V., and V. Clarke. 2006. "Using Thematic Analysis in Psychology.” Qualitative Research in Psychology 3 (2): 77-101.

Cameron, C. 2009. "Tragic but Brave or Just Crips with Chips?: Songs and their Lyrics in the 
Disability Arts Movement in Britain.” Popular Music 28 (3): 381-396.

Cameron, C. 2015. "Turning Experience into Theory: The Affirmation Model as a Tool for Critical Praxis.” Social Work \& Social Sciences Review 17 (3): 108-121.

Campbell, J., and M. Oliver. 1996. Disability Politics: Understanding Our Past, Changing Our Future. London: Routledge.

Clark, L. 2003. "Disabling Comedy: “Only When We Laugh!” Paper presented at Finding the Spotlight Conference, Liverpool Institute of the Performing Arts, May 20.

http://disability-studies.leeds.ac.uk/files/library/Clark-Laurence-clarke-on-comedy.pdf

Cockburn, P. 2012. "You've Got to Laugh: Disability Comedy." Access Magazine, October 18. http://www.accessmagazine.co.uk/disability-comedy/

Coser, R.L. 1959. "Some Social Functions of Laughter: A Study of Humor in a Hospital Setting." Human Relations 12 (2): 171-182.

Cross, S. 2012. "Laughing at Lunacy: Othering and Comic Ambiguity in Popular Humour About Mental Distress." Social Semiotics 23 (1): 1-17.

Dawson, R. 2014. Disability Arts Left Hanging by a Thread: A Response From Candodo, Candodo Dance Company, August 1. http://www.candoco.co.uk/2014/08/disability-arts-lefthanging-by-a-thread-a-response-from-candoco/

Double, O. 2014. Getting the Joke: The Inner Workings of Stand-up Comedy. $2^{\text {nd }}$ ed. London: Bloomsbury.

Fairclough, N. 1989. Language and Power. London: Longman.

Gardner, L. 2014. "Disability Arts Left Hanging by a Thread." The Guardian Theatre Blog, July 29. http://www.theguardian.com/stage/theatreblog/2014/jul/29/disability-arts-cutsaccess-to-work-theatre

Garfinkel, H. 1967. Studies in Ethnomethodology. Englewood Cliffs, NJ: Prentice-Hall.

Garland, R. 1995. Eye of the Beholder: Deformity and Disability in the Graeco-Roman World. Ithaca, New York: Cornell University Press.

Goffman, E. 1974. Interaction Ritual: Essays in Face to Face Behaviour. Garden City, NY: Doubleday.

Goffman, E. 1963. Stigma: Notes on the Management of Spoiled Identity. London: Penguin.

Haller, B. 2003. "DSQ Symposium, Disability \& Humor.” Disability Studies Quarterly 23 (3/4). http://dsq-sds.org/article/view/430/607

Haller, B., and S. Ralph. 2003. “John Callahan's Pelswick Cartoon and a New Phase of 
Disability Humor." Disability Studies Quarterly 23 (3/4). http://dsq-ds.org/article/view/ $431 / 608$

Hughes, H., and D. Román. eds. 1998. O Solo Homo: The New Queer Performance. New York: Grove.

Lisicki, B. 1992. "Nice Face, Shame About the Legs..! Confessions of a Disabled Female Stand-up Comic." In Disability Equality in the Classroom: A Human Rights Issue, edited by R. Rieser, and H. Mason, 66-67. London: Disability Equality in Education.

Mallet, R. 2009. "Choosing 'stereotypes': Debating the efficacy of (British) Disabilitycriticism.” Journal of Research in Special Educational Needs 9 (1): 4-11.

Mallet, R. 2010. "Claiming Comedic Immunity. Or, What do you get when you Cross Contemporary British Comedy with Disability." Review of Disability Studies 6 (3): 5-13.

Martin, N. 2010. "A Preliminary Study of Some Broad Disability Related Themes Within the Edinburgh Festival Fringe.” Disability \& Society 25 (5): 539-549.

Martinez, F. 2014. What the **** is Normal! London: Virgin Books.

Merrill, L. 1988. "Feminist Humor: Rebellious and Self-affirming." In Last Laughs:

Perspectives on Women and Comedy, edited by R. Barreca, 271-281. New York: Gordon \& Breach.

Mintz, L. 1985. "Stand-up Comedy as Social and Cultural Mediation.” American Quarterly 37: $71-80$.

Montgomerie, M. 2010. "Visibility, Empathy and Derision: Popular Television Representations of Disability." ALTER 4: 94-102.

O’Hara, M. 2006. "No Fear, No Frills.” Guardian Online, June 21. http:// www.guardian.co.uk/society/2006/jun/21/disability.socialcare

Provine, R. 2000. Laughter: A Scientific Investigation. London: Faber \& Faber.

Reid, K.D., E. Hammond Stoughton, and R.M. Smith. 2006. "The Humorous Construction of Disability: 'Stand-up' Comedians in the United States." Disability \& Society 21 (6): 629-643.

Reid-Hresko, B.A., and K.D. Reid. 2005. "Deconstructing Disability: Three Episodes of South Park." Disability Studies Quarterly 25 (4). http://dsq-sds.org/article/view/628/805

Reeve, D. 2004. "Psycho-emotional Dimensions of Disability and the Social Model." In Implementing the Social Model of Disability: Theory and Practice, edited by Barnes, C., and G. Mercer, 83-100. Leeds: Disability Press.

Ross, K. 2001. “All Ears: Radio, Reception and Discourses of Disability.” Media, Culture \& Society 23: 419-437. 
Rutter, J. 2000. “The Stand-up Introduction Sequence: Comparing Comedy Comperes.” Journal of Pragmatics 32: 463-483.

Sandhal, C. 2003. "Queering the Crip or Cripping the Queer? Intersections of Queer and Crip Identities in Solo Autobiographical Performance.” GLQ: A Journal of Lesbian and Gay Studies 9 (1-2): 25-56.

Shakespeare, T. 1999. “Joking a Part.” Body \& Society 5 (4): 47-52.

Simmons, C. 2013. "Comedians with Disabilities Act Troupe to be Features in Fundraiser for Pacific Pinball Museum." eNewsChannels, August 13. http://enewschannels.com/2013/08/13/ enc19258_201818.php/comedians-with-disabilities-act-troupe-to-be-featured-in-fundraiserfor-pacific-pinball-museum/

Simmons-Mackie, N., and J. Damico. 2011. "Access and Social Inclusion in Aphasia: Interactional Principles and Applications.” Aphasiology 21 (1): 81-97.

Sturgis, P. 2008. "Designing Samples." In Researching Social Life. $3^{\text {rd }}$ ed., edited by N. Gilbert, 165-181. London: Sage.

Swain, J., and S. French. 2000. "Towards an Affirmation Model of Disability," Disability \& Society 15 (4): 569-582.

Tannen, D. 1987. "Remarks on Discourse and Power." In Power Through Discourse, edited by L. Kedar, 3-10. Norwood, NJ: Ablex.

Thomas, C. 1999. Female Forms: Experiencing and Understanding Disability. Buckingham: Open University Press.

Thomas, P. 2011. “"Mate Crime': Ridicule, Hostility and Targeted Attacks Against Disabled People." Disability \& Society 26 (1): 107-111.

Tracey, E. 2012. "Disability Comedy at the Edinburgh Festival Fringe." BBC - The Ouch! Blog, August 9. http://www.bbc.co.uk/blogs/legacy/ouch/2012/08/

disability_comedy_at_the_edinb.html

United Nations. 2006. Convention on the Rights of Persons with Disabilities. http:// www.un.org/disabilities/convention/conventionfull.shtml

Verrent, J. 2014. "Disability - No Longer at the Fringe of the Fringe." The Huffington Post, August 24. http://www.huffingtonpost.co.uk/jo-verrent/edinburgh-fringe-disability-no-longerat-the-fringe_b_5704037.html

Weaver, S. 2010 “The 'Other' Laughs Back: Humour and Resistance in Anti-Racist Comedy.” Sociology 44 (1): 31-48. 